\title{
Marketing Responsibility in an Era of Economic and Climactic Challenge
}

\author{
In memory of Professor Michael J. Thomas.
}

\begin{abstract}
This paper is written in memory of Professor Michael J. Thomas and his lifetime contribution to marketing theory and practice. Michael has been an inspiration to many and in one of his most recent papers from 2008, he examined the marketing profession's responsibility towards society, communities and the ecology of the planet in the twenty first century in the light of climate change. In this paper we interpret some of Michael's thoughts, in the context of Chinese firms' increasing presence on the global economic stage and the consequent impact this may be having on future ecological stability, which he presaged. The paper presents a theoretical framework for a global strategy for sustainability, and provides a vision of marketing responsibility that embraces civic professionalism, social trusteeship and a strategy for sustainability. A case example of a Chinese industrial manufacturer illustrates a number of key points.
\end{abstract}




\title{
Marketing Responsibility in an Era of Economic and Climactic Challenge
}

\author{
Helen Borland, University of Birmingham and Stan Paliwoda, University of Strathclyde
}

\author{
In memory of Professor Michael J. Thomas.
}

\section{Dedication}

This paper is written in memory of Professor Michael $\mathbf{J}$ Thomas and in memory of his recognition of the need to change what he saw as the increasingly dubious reputation marketing has developed as the last resort of hucksters, carpet baggers, snake oil salesmen and second-hand car dealers, to the status of a profession with acknowledged standards of conduct, even with its own equivalent of the Hippocratic oath.

Michael was beginning to see himself as a post-modernist, challenging conventional thought on marketing theory and practice and, in one of his most recent papers 'Marketing responsibility in an era of climate change' he began to explore the marketing professions' responsibility towards human society and the wider natural environment.

The paper was published in the conference proceedings and subsequent edited book from the first International Marketing and Business in CEE Markets conference in Katowice, Poland in 2008. It was Michael's expressed desire that this paper reach a wide academic audience. The paper below is, thus, our interpretation of one of Michael's last papers. It highlights humanity's responsibility towards each other, towards other species, the environment, and especially our responsibility and quest for an ecologically sustainable future. Michael recognised that an epistemological shift is necessary if we are, truly, to confront the changes required, as illustrated by the final paragraph of his paper:

"I have pursued the idea that marketing is a metaphor for the nature of the times in which we live. For most of the $20^{\text {th }}$ century it represented the means by which we became efficient consumers, it was a driver of consistently improving living standards, rarely criticised as being either too manipulative or unconcerned about profligate use of the world's resources. The $21^{\text {st }}$ century will become preoccupied with the consequences of global warming, and the clash of cultures. What new roles will marketing have to play? Can the profession, and indeed the citizenry that it claims to serve, metamorphose into civic professionalism, working to save the planet from a very unpleasant and uncomfortable end? "(Thomas, 2008:540)

As we move into an era of Chinese economic supremacy, we marketers must face up to the responsibility we have towards balancing the progression of global economic development (and selling goods and services in global market systems) with our responsibility towards our cultural systems and the global ecological system (the global ecosystem), the home of all our economic wealth. In honour of Michael's memory and a lifetime dedicated to furthering marketing academic thought and practice, we have extended his work on marketing's 
responsibility in an era of climate change to highlight some of the key issues, lessons and opportunities for Chinese firms as they prepare to internationalise (and globalise) their business activities.

The purpose of this paper is, thus, threefold:

1. To illustrate Michael's concept of civic professionalism and social trusteeship as a future alternative to the current marketing profession's code of conduct.

2. To put this in the context of climate change and ecological sustainability as a model for firms everywhere.

3. To extrapolate lessons and opportunities for firms from developing economies as they move towards global domination of world economic markets and, suggest strategies for sustainability that they can, and should, adopt.

The hypothesis for the paper emerges as: whether it's possible for Chinese firms to embrace the needs of $21^{\text {st }}$ century global ecological sustainability in meeting their own economic requirements for development and financial prosperity.

A case example will be used to illustrate the point.

\section{Background}

Michael was concerned that marketers might become the "sightless psychopaths" of market forces (Ascherson, 1999; Thomas, 2002), gripped in the thrall of market capitalism with no overall vision of what they are trying to achieve. Purser et al. (1995) also remind us that from an epistemological perspective there are no limits to anthropocentrism. The consumption rhetoric that is mediated by the socio-economic domain of the dominant social paradigm and based on political, economic and technological progression (Kilbourne, 1998) is a means to an end that lacks an end-point, and has no overall goal, human or otherwise. Thus, economic growth, from this perspective, continues unlimited and unchecked until complete destruction of the physical environment and natural resource base is achieved, at which point humans are likely to have destroyed their environment and their ability to look after themselves (Zohar and Marshall, 2000 and 2004; Du Nann Winter and Koger, 2004; Capra, 2004; Porritt, 2007).

Although this may sound somewhat apocalyptic, it is also logical and obvious, unless collective human insight and intelligence can resolve the issue. Scholars and scientists have long recognised the finite nature of the Earth's resources, compounded by the exponential increase in human numbers and human aspiration for a 'better quality of life'. Michael suggested that rather than being a part of this problem, it is the marketing profession's responsibility to metamorphose and become a part of the solution (Thomas, 2008). He proposed that marketers need to become 'citizen professionals', people who take account of their political and social responsibility towards their community, country and to the environment in which they live. Marketing with a sense of community, social and environmental responsibility would then become a very different activity to the one that is common today, an activity he referred to as social trusteeship. As citizens and as professionals our responsibility would apply to every aspect of our lives. He also argued that currently the management profession suffers from "epistemopathology" which he defined as: 
"Epistemopathology is diseased, sick, and bad knowledge that is mechanically applied to contemporary (global) market systems, in self-serving ways, to identify and solve "impairment", suggesting that we fail to see the whole picture. Senge (2006) calls it "organisational learning disability", the failure of the organisation to understand its holistic role. The pursuit of the bottom line, the focus on shareholder value, ignoring the wider implications of the role of the corporate entity in society." (Thomas, 2008:534)

The following sections of this paper will expand on a number of Michael's themes, namely, marketing responsibility in global systems; the need to understand the holistic picture rather than dealing only with the immediate issues; the potential clash of human cultures; marketing's responsibility towards the impact that China is having on global ecosystems; and the need to understand the ecological context in which all market decisions are made.

\section{The Internationalisation of Chinese Firms and Climate Change}

The term Climate Change as it is used in common parlance today, is a metaphor for the environment and ecology of the planet. However, this has been simplified in common usage to represent just one natural element $\left(\mathrm{CO}_{2}\right)$. Carbon dioxide, although significant, is not the main cause of our problems. Carbon dioxide is a symptom of much wider problems, and symbolises the overuse of natural, non-renewable resources and the degradation of the ecology of the planet. The causes of our ecological problems are much deeper rooted, and lie in the attitudes, values and beliefs humans have towards the importance of their own existence (Borland, 2009) and the seemingly unfettered approach we have towards the expansion of the human race and its consumption of resources and land.

In thinking, firstly, about Chinese economic development and climate change/ecological issues, an appropriate place to start would seem to be the recent Copenhagen Summit which culminated in a stand-off between the USA and Chinese premiers on what constitutes fair limits for $\mathrm{CO}_{2}$ emissions. One might assume a conflict of eastern and western economic policy in dealing with the issue. Yet, on closer examination the underlying principles and roots of eastern and western economic philosophy are not so removed from one another, and, in fact, in the European enlightenment period of the eighteenth century Chinese economic philosophy was imported to the West, and integrated in the concepts of the 'rational state' and a minimalist or 'laissez-faire' (wu wei) economy (Hobson, 2004).

What does separate the East and West in international negotiations, however, are religious traditions. Confucianist ideology provides teachings that centre on seven themes: ritual, relationships, filial piety, loyalty, humanity, the gentleman and rectification of names; and Taoism offers a set of philosophical principles that promote virtue and integrity; harmony with the universe; a state of receptiveness, and most importantly defining a path or road to existence (or non-existence). Together, Confucianism and Taoism constitute a quasi-religion for many people in East Asia; which can appear at odds with the more individualistic and paternalistic Christian religions of the West (Gao, et al. 2010).

However, more stark in contrast than the East - West dimension of negotiations, is the human - nature dimension. Both cultural backgrounds appear to be deeply anthropocentric in their orientation, promoting human-centric needs and wants above all others (Purser et al. 1995). The second worrying aspect of current international trade and environmental negotiations is the focus on immediate concerns and goals, rather than coming together to plan, strategise 
and provide an environmental vision for the future. Senge (2006) refers to this as linear thinking rather than process or systems thinking, which, he suggests, is circular and more holistic. "Sometimes, the knottiest dilemmas, when seen from the systems point of view, aren't dilemmas at all. They are the artefacts of "snap-shot" rather than "process" thinking, and appear in a whole new light once you think consciously of change over time" (Senge, 2006: 65). Senge's philosophy holds that many of life's problems can be solved if we change the way we approach them and look at the big picture rather than focusing on the small individual issues. To distinguish the two, he refers to a focus on dynamic complexity rather than detail complexity. The principle, he suggests, evolves from understanding the interrelationships and interdependencies of the natural environment, which can also be applied within organisations and domestic situations. He, further, suggests that living systems have integrity. Their character depends on the whole. The same is true of organisations; to understand the most challenging managerial issues requires seeing the whole system that generates the issues (Senge, 2006: 66). If this is true, then understanding the process of Chinese economic development and the internationalisation of Chinese firms must be viewed from a systems perspective rather than a linear "snap-shot" perspective, as Michael suggested above.

\section{Systems Thinking}

Reflecting on Senge's (2006) work, Einstein (1905) reminds us that "If we are to solve the problems that plague us, our thinking must evolve beyond the level we were using when we created those problems in the first place." Yet, diplomatic, economic and political negotiations appear not to have heeded his advice. Michael understood the need for a holistic, integrated and systems-based approach in dealing with management issues, as outlined by Senge (2006) above. In a scientific context, a system is defined as: "A set of detailed methods, procedures and routines established or formulated to carry out a specific activity, perform a duty, or solve a problem. A system is a whole that cannot be divided into independent parts. The essential properties of a system taken as a whole, derive from the interaction of its parts, not their actions taken separately" (Ackoff, 1981: 64-65). Systems are circular in nature, closed-loop, interactive and interdependent. They represent how life functions on Earth. However, there is a tendency for firms to operate linear, 'snapshot' patterns of operation without consideration for the wider business or natural environment.

Ecosystems are natural systems involving both living and nonliving entities. They are also circular, closed-loop, interactive and interdependent. They are the basic unit of environmental analysis from which all energy generation, utilisation and consumption, for all species, is measured. Ecosystems support life in a unique, complex and diverse system of relationships and interdependencies which are fragile and prone to disturbance. An ecosystem is defined by Odum (1994) as: "Any unit that includes all of the organisms (ie. the community) in a given area interacting with the physical environment so that the flow of energy leads to clearly defined trophic structure, biotic diversity and material cycles (ie. exchange of materials between living and non-living parts) within the system."

Lovelock (2000) integrates the concepts of systems theory, ecosystems theory and Darwinianism into his Gaia theory and suggests that the Earth acts as a super-organism that is alive and actively self-regulating as a consequence of the organisms on its surface. These organisms maintain a state that is comfortable (perfect) for life in a state of homeostasis. 
However, Gaia does not provide preferential treatment to any specific species and, Lovelock (2000) suggests, that it is the functioning of the whole system that is important rather than any one particular species. Currently, the human race is the only species on Earth that does not live within the bounds of natural ecosystems and is, thus, the only species that does not live sustainably (Borland, 2009).

Climate change has become an emotive term with protagonists and supporters, but even more so the term 'sustainability', because at a very deep level most individuals recognise the need to change the way they live, behave and value the world around them, otherwise, as a consequence, it is we that will suffer in the long term (Hart, 1997; Capra, 2004; Du Nann Winter and Koger, 2004; Thomas, 2008; Borland, 2009). Achieving sustainability is the real issue for humanity, with or without increases in levels of $\mathrm{CO}_{2}$, it is our need to learn to live sustainably, within the bounds of what the global ecosystem can provide us, which is the real purpose, holy grail, goal and end-point for humanity, not the continuation of the insatiable desire to use up all our resources.

Belz and Peattie (2009) provide a useful starting point for delineating some of the properties of sustainability. These properties include a holistic and systems-based view, an open-ended time frame, a global perspective that focuses on ecological sustainability rather than economic efficiency, and a recognition of the intrinsic value of nature. Sustainability also entails the recognition of the finite limits of nature as a source of resources and a sink for wastes, and distinguishes between unlimited economic growth (an impossibility) and sustainable growth as a qualitative improvement in means and ends (Ekins 2000). Because a transformation to ecological sustainability entails a fundamentally different way of looking at the world, an examination of Chinese economic development needs an expansion of the current limits of enquiry that are more macro and systems-based in focus (Kilbourne 1998).

In the context of the firm and the system in which it operates, Senge (2006) proposes consideration of five disciplines in developing the concept of a 'learning organisation'. These five include: systems thinking; personal mastery; mental models; team learning and shared vision. However, it is systems thinking that he refers to as the 'fifth discipline'. The fifth discipline is the independent variable in his analysis in as much as the following four disciplines are dependent on systems thinking. Senge (2006) recognises that within firms, individuals need to think with a systems perspective rather than a linear perspective. He suggests that: "As the fifth discipline, systems thinking is the cornerstone of how 'learning organisations' think about their world" (Senge, 2006: 69). Seeing the major interrelationships underlying a problem leads to new insight into what might be done. The essence of the discipline of systems thinking lies in a shift of mind:

\section{- Seeing interrelationships rather than linear cause-effect chains, and \\ - Seeing processes of change rather than snapshots.}

He also suggests that: "Systems thinking shows us that there is no separate "other"; that you and someone, or something else are part of a single system. The cure lies in your relationship with the "enemy" (Senge, 2006: 67). Thus, in terms of understanding international climate change negotiations between East and West and, the internationalisation of Chinese firms, the systems perspective is not so much a debate about carbon levels, but takes a much broader view, and needs to be examined in terms of the future sustainability of humanity, and other species, on Earth and how we are going to plan for and achieve this. A comprehensive global 
sustainability plan and strategy needs to be put in place. Consequently, the two premiers were, in effect, arguing about the wrong thing. The challenge and opportunity for China, in its desire to continue its economic development at a time of ecological constraint, is how to go about it in an ecologically sustainable, and life enhancing way rather than, potentially, being the perpetrators of the end of western economic civilisation as we know it today, the very goal they are, in fact, trying to achieve.

\section{Unsustainable Chinese Strategies}

China and India combined are currently responsible for 2.4 billion people of the world's 7 billion total. This is estimated to rise to 3 billion by 2050, more than one third of total human numbers. Both economies are growing rapidly, between 7 and 10 per cent per annum, and consumption levels are soaring. But the sustainability challenges they face make the challenges in Europe pale into insignificance (Porritt, 2007). Chinese carbon-intensive middle class consumers are estimated to double in numbers from around 260 million today, to around 530 million in 2020, approximately twice as many people as in the USA today.

However, because China is experiencing such concentrated economic growth (Gao, et al. 2010), the country is now facing a dramatic 'sustainability squeeze' (Porritt, 2007) which is threatening an ecological meltdown, the early signs of which are that it is affecting people's livelihoods and health. Life expectancy, after rising from 35 to 71 years, is now declining again due to air and water pollution.

The World Bank has estimated that pollution is costing China 8 to 12 per cent of its $\$ 1.4$ trillion GDP, annually, in terms of health bills, disaster relief, lost agricultural productivity and environmental clean-up. Both President $\mathrm{Hu}$ Jintao and the Prime Minister Wen Jiabao are warning that rates of economic growth will have to be severely curbed to prevent further loss of critical ecological capital. The aspiration now is 'balanced developments', as measured by a new 'green GDP indicator'; although, it is not clear whether the official goal of quadrupling 2002 GDP by 2020 has been set aside as a result (Porritt, 2007).

Pan Yue, China's Deputy Environment Minister, sums up the situation:

"China's economic miracle will end soon because the environment can no longer keep pace. Five of the ten most polluted cities worldwide are in China; acid rain is falling on one third of our territory; half of the water in China's seven largest rivers is completely useless; a quarter of our citizens lack access to clean drinking water; a third of the urban population is breathing polluted air; less than a fifth of the rubbish in cities is treated and processed in an environmentally sustainable manner." (Der Spiegel, 2005)

It is because of the size of China, and the speed of its economic development, that this 'growth and sustainability' conflict looms so large in global terms. The knock-on effect of this for the rest of the world will be profound. China must feed 20 per cent of the world's population on just 7 per cent of the world's arable land. In 2004, China became a net importer of food for the first time in its history. Prime agricultural land is being lost to urban industrial development, as a result, China's leaders have had to impose a moratorium on all 'green field developments' since 2004.

Land, water and energy are all in short supply and causing economic and ecological disruption, yet, at the 2007 G8+5 Summit in Germany, China's President made it clear that 
economic growth took precedence over addressing the challenge of climate change. With its huge population, China has a responsibility to its own people and to the rest of the world. The International Energy Agency shocked the world in April 2007 when it announced that China would overtake the USA as the world's largest emitter of $\mathrm{CO}_{2}$ not by 2025 as projected in 2004, not by 2010 - its 2006 projection, but by the end of 2007; emitting more than 6 billion tonnes in comparison to America's 5.9 billion tonnes. The fact that a substantial share of China's emissions can be attributed to the manufacture of exports to the first world, with 40 per cent ending up in the USA, is relevant, and the UK Prime Minister made an important observation when he said, at the Summit, that the success or failure of international diplomacy around climate change depends on how China and the USA address their respective responsibilities.

With foreign reserves of approximately $\$ 470$ billion, China can buy its way out of some of its resource constraints such as raw materials and being deficient in energy. This is what it is doing by importing 40 per cent of its oil, and also importing food, timber, steel and chemical feed stocks. This has a massive impact on global markets. But it's more difficult for the country to buy fertile topsoil, fresh clean water and indigenous forests.

As a result, China's energy and resource constraints are driving an aggressive programme of innovation with companies such as Shell and Sasol increasing their level of investment in China. The result is that China may become a major exporter of these technologies in the future. However, their current position is weak with major inefficiencies in the use of all energy forms. It takes at least seven times as much energy for China to produce the same amount of economic output as Japan (Porritt, 2007).

With China's population still growing at between $8-10$ million a year (estimated to peak in 2030 at 1.46 billion) and with the purchasing power of the middle classes still soaring, this is a titanic struggle. The political challenge for China's leaders is to weigh up the conflicting imperatives of economic development, the ecological degradation that is undermining its ability to maintain economic growth, and the consequent increase in social instability that is sweeping the country (Porritt, 2007). For the rest of the world, what's happening in China provides a window on the sort of resource constraints and ecological dilemmas that we, too, will soon be facing. We hope that the Chinese leadership will have the skills to balance all their different needs and assets in a truly integrated and sustainable way.

\section{Global Strategy for Sustainability}

In bringing together thoughts from Michael's paper on marketing's responsibility in an era of climate change; Senge's thoughts on systems thinking, the learning organisation and the ecological imperative of learning to live within non-negotiable ecological limits; and the impact China is having on global economic development, the authors propose that a comprehensive global sustainability plan and strategy needs to be developed, that will provide a broad framework for future global economic development and stability.

For this we need to return to Michael's idea of the epistemopathology of modern management, and propose a change in the epistemological basis of the current capitalist, dominant social paradigm, and management systems that spring from it. A number of authors have proposed alternatives based on the ecological imperative. Dunlap et al. (2000) suggest a new ecological paradigm (NEP), and Purser et al. (1995) propose the ecocentric 
responsibility paradigm (ERP). Both offer a rebalancing of human economic and social needs with the needs of the biophysical world, emphasising that, in fact, it is the ecology of the planet that supports all human activity and is, thus, the most important source of 'capital' in the human economic system. With this changed perspective it becomes much easier to begin to plan global priorities in terms of long term sustainable strategies.

Given that China is becoming the largest global player (Paliwoda and Slater, 2009), it falls on this country to lead the way in developing a global sustainability strategy, which if successful will undoubtedly become a major 'knowledge-based' export strength in the future. It will also fall upon Chinese firms to adopt such a strategy when internationalising their activities. The essential components of this strategy will include elements of: population control (and preferably sustained reduction); consumption control and a change in the types of products made and the way in which they are made, and disposed of; sustained appropriate habitat reconstruction (rather than destruction); an enlightened political system that encourages ecologically sustainable economic development; re-education of the population to understand the principles of the ecological imperative and sustainability as it applies today; and the development of a global sustainability vision that incorporates all nations.

Incorporating these six components will provide a 'transformational' change to the way economic development is conceived and managed, and it will be the responsibility of political leaders, corporate leaders and marketing leaders to initiate and maintain the change. Transformational strategies (Borland, 2009) emerge from an ecocentric epistemology (Purser et al. 1995; Dunlap et al. 2000) and embrace ecological sustainability, working within the constraints of natural ecosystems (Porter and van der Linde 1995a and 1995b; Sharma et al. 1999; Senge and Carstedt 2001; Hall and Vredenburg 2003; Pujari et al. 2003; Pujari et al. 2004; Seitz and Peattie 2004; Child et al. 2005; Slater et al. 2007; Porter 2008; Nidumolu et al. 2009).

In particular, McDonough and Braungart (2002) realised that the main issue for corporatelevel ecological sustainability is a question of the design of physical products, of all kinds. Using the term eco-effectiveness, they suggest that all products should be designed in the future to reflect the way in which nature designs and processes materials, so that they are made from only two types of materials: biological nutrients and technical nutrients. Biological nutrients are materials that biodegrade and can be returned to the biological cycle without causing any damage to it. Technical nutrients are materials that do not biodegrade but can be circulated continuously through the industrial cycle, thus eliminating waste and pollution, and reducing virgin resource use. If adopted, globally, this, we suggest, would provide a more positive outlook for the future of humankind and would allow humans to continue with their current lifestyles and quality of life without the guilt trip.

\section{Case Example - Towards a Sustainability Strategy (Transformational, eco-effective, closed-loop, industrial ecosystems).}

Company $\mathrm{X}$ is a manufacturer of waxes sold to other manufacturers to make consumer wax products. Traditionally, wax manufacture has involved contamination of waste water and toxic air pollution. In China, company $\mathrm{X}$ (disguised for confidentiality reasons) became concerned because the effluent water was killing flora and fauna in the nearby lake which was also a major tourist attraction and popular destination for the locals. Recently, the company decided to take the situation into its own hands and changed the technology and 
processing of the wax product. Since initiating the production of AKD wax, the company has been able to eliminate acids and chlorine from processing, which has meant that the waste water no longer contains these dangerous contaminants. This has had a major positive impact on the manufacturing process in that it has reduced, almost eliminated, water pollution and also saved the company money in eliminating one processing step plus the cost of disposal of the contaminants. The water that was previously discarded as, too dangerous to reuse, is now continuously re-circulated in the manufacturing process, thus closing the manufacturing loop and, additionally, saving the company money on its water bill. Company X still has further improvements to make in terms of improving its sustainability credentials but its actions, to date, have earned it the title of one of China's most innovative chemical companies with a technology patent and a number of awards gained. The money saved will, in due course, be invested back into further sustainability initiatives, and importantly it has gained itself a unique competitive advantage in the marketplace which is generating increased sales opportunities worldwide. Company X now sells to manufacturers in Canada, the USA, South America, Europe, Australia, South East Asia and Russia, meeting international environmental standards and regulations.

Although company $\mathrm{X}$ has begun its transformational change to a sustainability strategy by changing the way it makes product; initiating the reconstruction of the local habitat in and around the lake, thus also improving the local environment for the human community; and reeducating its industrial customers around the world, it still has a way to go, particularly, in the area of the transportation of industrial products around the world. From a sustainability perspective, this would be better achieved by using a network of local suppliers in each region (Kolk, 2010) who are able to adapt to the needs of the local ecology and human communities, thus adopting what Vrontis et al. (2009) refer to as 'glocalisation' organisations that are able to think globally yet act locally.

\section{A Vision of Marketing Responsibility}

In creating a vision of marketing responsibility in an era of climate change, we return once more to Michael's vision of civic professionals and social trusteeship. The new marketing responsibility will be one of influencing and educating each consumer/citizen to play their part in creating and maintaining an ecologically sustainable economy consistent with a global sustainability strategy, in order that we can all help to provide the kind of societies and communities we wish to live in.

Although changing the emphasis and putting the ecological imperative first may seem unpalatable to some at this time, the realisation of the dangers and impending crisis that looms in front of us should be sufficient motivation to change attitudes and behaviours.

In adopting the above components of a global strategy for sustainability such as population control, consumption control, habitat reconstruction, political enlightenment, population reeducation and a global sustainability vision, the marketing agenda begins to look very different. The authors propose that marketing's responsibility in an era of climate change and sustainability will include:

- A marketing that adopts a balanced view with regard to the longer term effects of all that we engage in from packaging to food production, where longer term needs must be given more consideration than short term effects. 
- An overall marketing agenda that is consistent with a global strategy and plan for longer-term ecological sustainability.

- A marketing that encourages the design, manufacture, consumption and disposal of eco-effective products and services.

- A marketing that teaches people about their individual responsibility towards their family, community, environment and the future sustainability of the planet.

- A marketing that promotes sensible family size worldwide, with no more than two children per family, but primarily encourages the adoption of orphans.

- A marketing that seeks financial investment from governments that supports ecoeffective industry and firm development for future economic stability, collaboration and competitiveness.

- A marketing that encourages energy use from renewable resources such as solar and biogas, at both a commercial and domestic level.

- A marketing that supports habitat reconstruction and the preservation of and respect for other species, promoting preservation of specified amounts of land for every 1,000 human births, consistent with biological carrying capacity calculations.

Marketing is the management function responsible for communicating with consumers/citizens, influencing, and persuading their thought processes and their behaviour patterns. Therefore, in the twenty first century it is time for marketing to mature as a discipline and as a profession, become post-modern, and put these powers and skills to good use rather than to continue with the outdated and outmoded, self-gratifying approach of the twentieth century, as indicated by Michael at the beginning of this paper. To quote Michael's concluding paragraph once more: What new roles will marketing have to play? Can the profession, and indeed the citizenry that it claims to serve, metamorphose into civic professionalism, working to save the planet from a very unpleasant and uncomfortable end? (Thomas, 2008: 540). Can we, therefore, change the standards of our profession with the equivalent of the Hippocratic oath, and become recognised as part of the solution for sustainability rather than a part of the problem?

The authors conclude this section by offering a new definition of sustainability marketing:

Companies that satisfy the needs of industrial and consumer markets whilst remaining within biophysical constraints, and only exploiting resources at a rate at which they can be sustainably maintained, recovered or replenished in cradle to cradle, closed-loop ecological systems.

\section{Conclusions and Implications}

The purpose of this paper has been to commemorate Professor Michael Thomas' contribution to marketing thought and practice and, in particular, to provide further exposure to his idea of civic professionalism and social trusteeship in an era of climate change. Michael (Thomas, 
2008) emphasised the need for the marketing profession to take more responsibility for its actions, and its old philosophy that encourages the profligate use of the world's resources, and endless consumption. He posed the questions: 'What new role will marketing have to play?' and can the marketing profession metamorphose towards a philosophy that will allow it to work towards helping to save (us) the planet?' This paper has presented a new vision, role and responsibility that is consistent with Michael's vision for twenty first century marketing to become more ecologically sustainable and caring towards all species.

Given that China is now the largest global economic power and one of the largest exporters of manufactured goods, it is appropriate to apply Michael's ideas to the economic and market systems of that nation. Whilst China has many ecological and environmental problems consistent with, old style, industrial development, there is hope for the future, that it can recognise and adopt, in time, strategies for sustainability that will allow it to transform its manufacturing and business practices. This will, in turn, provide the opportunity for the Chinese marketing profession to transform itself towards its responsibility to its country, communities and environment, and in the future export 'knowledge-based' sustainability expertise. Michael's lasting contribution to our profession is his vision for a better world in which individuals, communities, countries, and the global ecosystem can flourish and prosper together, and not self-destruct as is the current prognosis. We hope twenty first century humanity can make it happen. 


\section{References}

Ackoff, (1981). Creating the corporate future: Plan or be planned for. New York: John Wiley and Sons.

Ascherson, N. (1999). The Indispensable Englishman, New Statesman, 29 January.

Belz, F. M. and Peattie, K. (2009). Sustainability marketing: A global perspective. Chichester: John Wiley and Sons Ltd.

Borland, H. (2009). Conceptualising global strategic sustainability and corporate transformational change, International Marketing Review, 26(4/5), 554-572.

Capra, F. (2004). The hidden connections: A science for sustainable living. New York: Anchor Books.

Child, J., Faulkner, D. and Tallman, S. (2005). Cooperative strategy. Oxford: Oxford University Press.

Der Spiegel (2005), interview with Pan Yue by Andreas Lorenz, published $7^{\text {th }}$ March.

Du Nann Winter, D. and Koger, S. (2004). The psychology of environmental problems. $2^{\text {nd }}$ Edition, Mahwah, New Jersey: Lawrence Erlbaum Associates/Eurospan (London).

Dunlap, R., Van Liere, K., Mertig, A. and Jones, R. (2000). New trends in measuring environmental attitudes: Measuring endorsement of the new ecological paradigm: A revised NEP scale. Journal of Social Issues, 56(Fall), 425-442.

Ekins, P. (2000). Economic growth and environmental sustainability. London: Routledge.

Einstein, A. (1905), in McDonough, W. and Braungart, M. (2002). Cradle to cradle: Remaking the way we make things. New York: North Point Press, pp. 165.

Gao H., Ballantyne, D. and Knight, J. (2010). Paradoxes and guanxi dilemmas in emerging Chinese - Western intercultural relationships, Industrial Marketing Management, 39(2), 264-272.

Hall, J. and Vredenburg, H. (2003). The challenges of innovating for sustainable development, MIT Sloan Management Review, 45(1), 61-68.

Hart, S. (1997). Beyond greening: Strategies for a sustainable world. Harvard Business Review, 75(1), 66-76.

Hobson, J. (2004) The Eastern origins of Western civilisation, Cambridge: Cambridge University Press.

Kilbourne, W. E. (1998). Green marketing: A theoretical perspective. Journal of Marketing Management, 14, 641-655.

Kolk, A. (2010). Social and sustainability dimensions of regionalisation and (semi)globalisation, The Multinational Business Review, 18(1), 51-72.

Lindbloom, C. (1990). Inquiry and change: The troubled attempt to understand and shape society, New Haven, Yale University Press. 
Lovelock, J. (2000). The ages of Gaia: A biography of our living earth. New York: Bantam.

McDonough, W. and Braungart, M. (2002). Cradle to cradle: Remaking the way we make things. New York: North Point Press.

Nidumolu, R., Prahalad, C. K. and Rangaswami, M. R. (2009). Why sustainability is now the key driver of innovation, Harvard Business Review, September, 57-64.

Odum, E. (1994). Ecological and general systems: An introduction to systems ecology, Niwot, Colorado, USA: University Press of Colorado.

Paliwoda, S. and Slater, S. (2009). Globalisation through the kaleidoscope. International Marketing Review, 26(4/5), 373-383.

Porritt, J. (2007). Capitalism as if the World matters. London: Earthscan.

Porter, M. E. and van der Linde, C. (1995a). Green and competitive: Ending the stalemate. Harvard Business Review, 73(5), 120-134.

Porter, M. E. and van der Linde, C. (1995b). Towards a new conception of the environment: Competitiveness relationships. Journal of Economic Perspectives, 9(4), 97-118.

Porter, M. (2008). The five competitive forces that shape strategy. Harvard Business Review, January, 79-93.

Pujari, D. Wright, G. and Peattie, K. (2003). Green and competitive: Influences on environmental new product development performance. Journal of Business Research, $56(8), 657-671$.

Pujari, D. Peattie, K. and Wright, G. (2004). Organisational antecedents of environmental responsiveness in industrial new product development. Industrial Marketing Management, 33(5), 381-391.

Purser, R. E., Park, C. and Montuori, A. (1995). Limits to anthropocentrism: Toward an ecocentric organization paradigm? Academy of Management Review, 20(4), 1053-1089.

Seitz, M. and Peattie, K. (2004). Meeting the closed-loop challenge: The case of remanufacturing. California Management Review, 46(2), 74-89.

Senge, P. (2006) The Fifth Discipline: The art and practice of the learning organisation, London: Random House.

Senge, P. and Carstedt, G. (2001). Innovating our way to the next industrial revolution. MIT Sloan Management Review, 42, 24-38.

Sharma, S., Pablo, A. and Vredenburg, H. (1999). Corporate environmental responsiveness strategies. The Journal of Applied Behavioral Science, 35(1), 87-108.

Slater, S. F., Hult, G. T. M., and Olson, E. M. (2007). On the importance of matching strategic behaviour and target market selection, Journal of the Academy of Marketing Science, 35(1), 5-17.

Thomas, M. J. (2002). Thoughts on building a just market society, Journal of Public Affairs, 2(2), 9-15. 
Thomas, M. J. (2008). Marketing responsibility in an era of climate change, in International Marketing and Business in the CEE Markets, Ed. Maja Szymura-Tyc, Poland, University of Economics in Katowice.

Vrontis, D., Thrassou, A. and Lamprianou, I. (2009). International marketing adaptation versus standardisation of multinational companies. International Marketing Review, 26(4/5), 477-500.

Zohar, D. and Marshall, I. (2000). Spiritual intelligence: The ultimate intelligence. London: Bloomsbury.

Zohar, D. and Marshall, I. (2004). Spiritual capital: Wealth we can live by. San Francisco: Berrett-Koehler. 